\title{
The investigation of the evolution of diffusional properties of nonequilibrium grain boundaries during annealing of submicrocrystalline materials
}

\author{
V.N. Perevezentsev ${ }^{1,2}$, A.S. Pupynin ${ }^{\dagger, 1}$, A.E. Ogorodnikov ${ }^{2}$ \\ 'pupynin.as@gmail.com
}

\begin{abstract}
${ }^{1}$ Mechanical Engineering Research Institute, RAS, 85 Belinsky St., Nizhny Novgorod, 603024, Russia ${ }^{2}$ Lobachevsky State University of Nizhny Novgorod, 23/3 Gagarin Av., Nizhny Novgorod, 603950, Russia
\end{abstract}

\begin{abstract}
A model is proposed that allows one to describe a change in the nonequilibrium state and diffusion properties of grain boundaries during low-temperature annealing of submicrocrystalline materials containing in the initial state a system of grain-boundary nano-cavities. It is shown that the dissolution of grain-boundary cavities during annealing leads to the emission of vacancies from the cavities into the grain boundaries and to an increase in the nonequilibrium free volume of the grain boundaries. As a result, the coefficient of grain-boundary diffusion, which is exponentially dependent on the value of the free volume of grain boundaries, also changes. The influence of the initial value of the volume fraction of grain-boundary cavities and the initial value of the nonequilibrium free volume of grain boundaries on the kinetics of cavity dissolution and the dependence of the grain-boundary diffusion coefficient on the annealing time is analyzed. It is established that this dependence has three stages. The first stage is characterized by a slow increase in the coefficient of grain-boundary diffusion due to the fact that the process of vacancies emission into the grain boundaries associated with the dissolution of cavities is equalized by the outflux of nonequilibrium vacancies from the boundaries into the grain volume. The short-term second stage is characterized by a sharp increase in the coefficient of grain-boundary diffusion and is associated with the rapid collapse of the cavities when they reach a critical radius. At this stage, the coefficient of grain-boundary diffusion may exceed by 1-2 orders of magnitude its value for the equilibrium grain boundaries. The third stage is characterized by a slow decrease of the diffusion coefficient and is associated with the outflux of nonequilibrium vacancies into the grain volume. Thus, contrary to the prevailing ideas that annealing is always accompanied by the transition of grain boundaries into a more equilibrium state, it has been shown that in the case of low-temperature annealing of submicrocrystalline materials containing in the initial state grain boundary cavities, the reverse process can occur, i. e. an increase in the nonequilibrium state of grain boundaries caused by a change of its nonequilibrium free volume during the dissolution of cavities. It is shown that the nonequilibrium state of grain boundaries can be maintained for a long time of annealing.
\end{abstract}

Keywords: submicrocrystalline materials, nonequilibrium grain boundaries, grain boundary diffusion, grain boundary cavities.

УДК: 620.186.8:539.219.3:539.374.001

\section{Исследование эволюции диффузионных свойств неравновесных границ зерен при отжиге субмикрокристаллических материалов}

\author{
Перевезенцев В.Н., ${ }^{1,2}$, Пупынин А.С. ${ }^{\dagger, 1}$, Огородников А.Е. ${ }^{2}$ \\ †pupynin.as@gmail.com
}

\footnotetext{
${ }^{1}$ Институт проблем машиностроения РАН, ул. Белинского, 85, Нижний Новгород, 603024, Россия

${ }^{2}$ Нижегородский государственный университет им. Н. И. Лобачевского, пр. Гагарина 23/3, Нижний Новгород, 603950, Россия
} 
Предложена модель, позволяющая описать изменение неравновесного состояния и диффузионных свойств границ зёрен в процессе низкотемпературного отжига субмикрокристаллических материалов, содержащих в исходном состоянии систему зернограничных нанопор. Показано, что растворение зернограничных пор при отжиге приводит к эмиссии вакансий из пор в границы зёрен и увеличению неравновесного свободного объёма границ зёрен. Как следствие, изменяется и коэффициент зернограничной диффузии, экспоненциально зависящий от величины свободного объёма границ зёрен. Проанализировано влияние исходного значения объемной доли зернограничных пор и начального значения неравновесного свободного объёма границ зёрен на кинетику растворения пор и зависимость коэффициента зернограничной диффузии от времени отжига. Установлено, что эта зависимость имеет три стадии. Для первой стадии характерно медленное увеличение коэффициента зернограничной диффузии вследствие того, что процесс генерации вакансий в границы зёрен, связанный с растворением пор, уравновешивается процессом оттока неравновесных вакансий с границ в объём зёрен. Непродолжительная вторая стадия характеризуется резким увеличением коэффициента зернограничной диффузии и связана с быстрым схлопыванием пор при достижении ими критического радиуса. На этой стадии коэффициент зернограничной диффузии может превышать на 1-2 порядка его значение для равновесных границ зёрен. Третья стадия характеризуется медленным процессом уменьшения коэффициента диффузии и связана с оттоком неравновесных вакансий в объём зёрен. Таким образом, вопреки сложившимся представлениям о том, что отжиг всегда сопровождается переходом границ зёрен в более равновесное состояние, показано, что в случае низкотемпературного отжига субмикрокристаллических материалов, содержащих в исходном состоянии зернограничные поры, может осуществляться и обратный процесс - увеличение степени неравновесности границ зёрен, вызванное изменением их неравновесного свободного объема в процессе растворения пор. Показано, что неравновесное состояние границ зёрен может поддерживаться в течение длительного времени отжига.

Ключевые слова: субмикрокристаллические материалы, зернограничная диффузия, неравновесные границы зёрен, поры.

\section{Introduction}

Submicrocrystalline (SMC) materials produced by methods of severe plastic deformation (SPD) possess unique physicomechanical properties $[1,2]$. However, after SPD treatment, a decrease in durability of the SMC materials under sustained loading is often observed. In the works of V.I. Betekhtin and coauthors $[3,4]$ it is shown that this effect may be due to the presence of initial cavities in the SMC materials. In the works of Yu. R. Kolobov, G. P. Grabovetskaya etal. [5-9], the effect of preliminary annealing for one hour on the creep of singlephase commercially pure SMC metals (titanium, nickel, copper and molybdenum), as well as the two-phase $\alpha+\beta$ titanium SMC alloy Ti-6Al-4V and the composite $\mathrm{Cu}-\mathrm{Al}_{2} \mathrm{O}_{3}$ containing dispersed particles of the second phase, was studied. With an increase in the annealing temperature, they discovered an increase in the strain rate at the steady-state creep stage. Moreover, since both annealing and subsequent deformation did not affect the average grain size of the material, the authors [5-9] concluded that an increase in the strain rate (the main contribution to which in the case of SMC materials is made by grain boundary sliding) is caused by the influence of annealing on the nonequilibrium state of grain boundaries (GB). In [10], the acceleration of creep after preliminary annealing was observed on the SMC aluminum alloy 1570 .

As a possible cause of the effect of annealing on the creep rate of SMC alloys, the authors of [10] considered the increase in the nonequilibrium GB excess volume as a result of the dissolution of grain-boundary nanocavities, leading to the increase in the grain-boundary diffusion rate and the rate of sliding along the GB.

Nanocavities on GBs and in triple junctions (TJs) of grains were observed after SPD treatment in Al [11-14], $\mathrm{Cu}$ [15-18], Ni [19-21], and Ti [22,23] and their alloys. The micromechanisms and the conditions of nanocavity nucleation in SMC materials were discussed in [24].
Theoretically, the process of dissolution of the grainboundary cavities during annealing was investigated in [25]. Later, the model proposed by the authors of this work was modified to analyze the kinetics of growth and dissolution of nanocavities upon annealing of SMC materials [26]. In [27], the effect of internal stresses from mesodefects arising during SPD in TJs [28-30] was analyzed, as well as the effect of a nonequilibrium state (nonequilibrium free volume) of GBs, changing during annealing, on the dissolution kinetics of nanocavities in the process of low-temperature annealing of SMC materials. In this case, only cavities located along the TJs of the SMC materials with a relatively small initial volume fraction of cavities were considered.

In the present work, a theoretical study of the effect of the dissolution of grain-boundary nanocavities upon low-temperature annealing of SMC materials on the nonequilibrium state and diffusion properties of GBs is carried out. The kinetics of cavity dissolution and the dependence of the coefficient of grain-boundary diffusion on the initial values of the nonequilibrium free volume of the GBs and the volume fraction of grain-boundary cavities are analyzed.

\section{Description of the model}

The dissolution of grain-boundary cavities in the course of annealing should lead to the emission of nonequilibrium vacancies in the GBs. In the disordered atomic structure of ordinary GBs, vacancies are unstable and delocalized. All this leads to an increase in the nonequilibrium free volume of the GBs and, as a result, to an increase in the coefficient of grain-boundary diffusion [31]. At the same time, the saturation of the GBs by nonequilibrium vacancies leads to the equalization of the chemical potentials of atoms on the cavity surface and in the GBs. As a result, at a sufficiently large initial concentration of grain-boundary cavities, a quasi-stationary regime occurs, at which the rate of change 
of a nonequilibrium free volume of the GBs is limited by the outflux of vacancies into the volume of the grains.

In the case of low-temperature annealing, diffusion processes in the volume of the grains proceed rather slowly, which should significantly affect the duration of the relaxation process of the nonequilibrium state of the GBs. As the analysis shows, with the parameters of the task considered below, the time taken for this process is significantly greater than the characteristic relaxation time of the elastic stress fields from junction disclinations [27]. Therefore, to illustrate the effect of cavity dissolution on the evolution of a nonequilibrium free volume and the diffusion properties of GBs during annealing, a model polycrystal containing only an ensemble of spherical nanocavities of radius $r$ uniformly distributed in GBs at a distance $\lambda$ from each other is considered further on.

\subsection{The evolution of cavities during low-temperature annealing}

At sufficiently low annealing temperatures, when the diffusion of atoms from the grain volume to the cavity can be neglected, the change in the volume of the grain boundary cavity occurs by short-circuited (in the region of order $\lambda / 2$ in size) diffusion flows of grain boundary atoms. The driving force of mass transfer is the gradient of the chemical potentials of atoms $\nabla \mu \approx 2\left(\mu_{b}-\mu_{s}\right) / \lambda$, where $\mu_{b}$ is the chemical potential of atoms of a nonequilibrium GB [27]:

$$
\mu_{b}=\frac{K_{b} \Omega}{2} f-k T \ln \left(1+\frac{f}{f^{*}}\right)
$$

and $\mu_{s}$ is the chemical potential of atoms on the cavity surface:

$$
\mu_{s}=2 \gamma_{s} \Omega / r
$$

$f$ and $f^{*}$ are the relative free volume of nonequilibrium and equilibrium GB, respectively, $\Omega$ is the atom volume, $K_{b}$ is the bulk modulus (modulus of compression), $k$ is the Boltzmann constant, $T$ is the annealing temperature.

In this model, it is assumed that there is no diffusion interaction between neighboring cavities. In this approximation, the equation for the rate of change of the cavity volume is:

$$
\begin{aligned}
\dot{V} & =\frac{4 \pi \sqrt{5}}{3} \frac{\delta D_{b}}{k T} \frac{r}{\lambda} \times \\
& \times\left[0.5 K_{b} \Omega f-k T \ln \left(1+\frac{f}{f^{*}}\right)-\frac{2 \gamma_{s} \Omega}{r}\right],
\end{aligned}
$$

where $D_{b}$ is the coefficient of grain-boundary diffusion, $\delta \approx 2 b$ is the width of the GB, $b$ is the Burgers vector.

\subsection{The change in the nonequilibrium state of the $G B$ and the coefficient of grain boundary diffusion in the annealing process}

According to [31], the relationship between the coefficient of grain-boundary diffusion and the magnitude of the relative free volume of the GB is as follows:

$$
D_{b}=D_{b}^{*} \exp (\alpha f)
$$

where $D_{b}^{*}$ is the diffusion coefficient along equilibrium GBs, $\alpha=K_{b} \Omega / 2 k T$.

The rate of accumulation of a nonequilibrium free volume of a GB is determined by two processes - the dissolution of cavities and the associated emission of nonequilibrium vacancies in the $G B$, and their outflux into the neighboring volume of grains. Based on this, the kinetic balance equation for the relative nonequilibrium free volume $f$ can be written in the form:

$$
\dot{f}=-\frac{\dot{V}}{4 \delta \lambda^{2}}-\frac{2 \Omega}{\delta}\left[A_{0} \exp (\alpha f)-B C_{v}(x=0)\right],
$$

where the first term describes the change in $f$ in the process of nanocavity dissolution [27], and the second one describes its change in the exchange of vacancies between the GBs and the volume of grains [32-34]. Here [32-34]: $A_{0}=\left(\omega_{b} / b^{2}\right) \exp \left[-\left(F_{v f}^{c r}+\Delta F+0.5 K_{b} \Omega f^{*}\right) / k T\right], F_{v f}^{c r}-$ is the free energy of the formation of a lattice vacancy, $\Delta F$ is the free energy activation of atom jump from the grain volume to the grain-boundary vacancy, $B=b \omega_{c} \exp (-\Delta F / k T)$, $\omega_{b}$ and $\omega_{c}$-are the oscillation frequency of atoms in the $\mathrm{GB}$ and in the crystal lattice, respectively $C_{v}(x=0)$ is the concentration of vacancies near GBs. When writing equation (5), it was assumed that the nonequilibrium free volume is uniformly distributed over the GB. This assumption seems justified at sufficiently small distances between the cavities.

Equations (3)-(5), supplemented by the standard equation for the volume diffusion of vacancies with the boundary conditions given in [32-34], form a closed system that allows analyzing the influence of various factors on the kinetics of the evolution of diffusion properties of nonequilibrium GB during annealing.

\section{Results of numerical calculations and discussion}

The calculations were carried out for the case of lowtemperature annealing $\left(T=0.4 T_{m}\right)$ of SMC aluminum with a grain size $d=4 \cdot 10^{-7} \mathrm{~m}$ with the following values of the parameters: $b=2.86 \cdot 10^{-10} \mathrm{~m}, \Omega=b^{3}, \omega_{b} \approx \omega_{c}=10^{13} \mathrm{c}^{-1}$, $f^{\star}=2 \cdot 10^{-2}, \quad H_{v f}^{c r}=10 k T_{m}, \quad S_{v f}^{c r}=4 k, \quad \Delta F=8 k T_{m} \quad$ [34], $D_{b}=1.5 \cdot 10^{-16} \mathrm{~m}^{2} / \mathrm{s}$ [35]. For the value of the free surface energy, the estimation $\gamma_{s}=G b / 8$ was used.

The initial cavity size $r_{0}$ was selected from the equilibrium condition of the cavity $(\dot{V}=0$ in equation (3)) for a given initial value of the relative free volume $f=f_{0}$ :

$$
r_{0}=2 \gamma_{s} \Omega /\left[0.5 K_{b} \Omega f_{0}-k T \ln \left(1+f_{0} / f^{*}\right)\right] .
$$

Fig. 1-3 shows the results of calculations of the dependences of the nonequilibrium free volume of GBs $f$ (Fig. 1), the coefficient of grain-boundary diffusion $D_{b}$ (Fig. 2) and the radius of grain-boundary cavities $r$ (Fig. 3) on the annealing time $t_{a}$ for different initial values of the volume fraction of grain-boundary cavities $v_{0}$ and various initial degree of nonequilibrium $f_{0}$.

It can be seen that the dependences $f\left(t_{a}\right)$ и $D_{b}\left(t_{a}\right)$ have three characteristic stages. At the first stage, the process of dissolution of grain-boundary cavities occurs slowly; therefore, the magnitude of the nonequilibrium free volume of the GB, and, therefore, the coefficient 


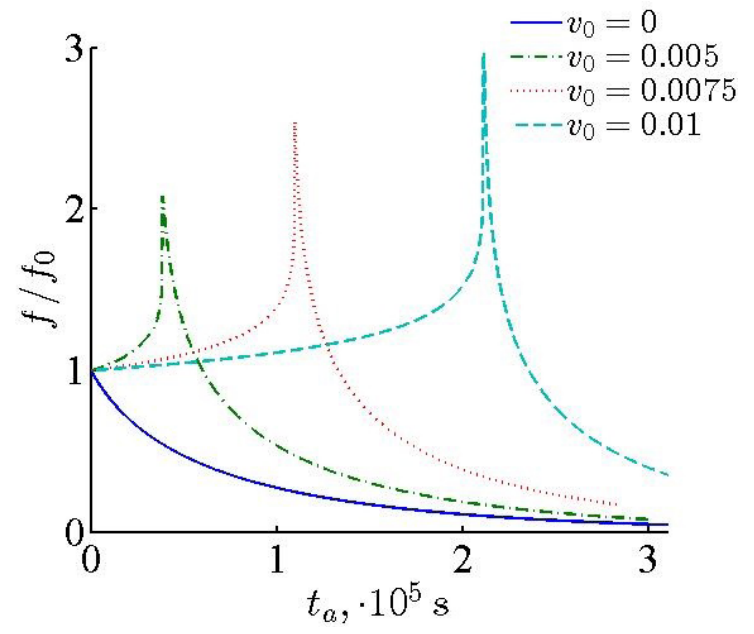

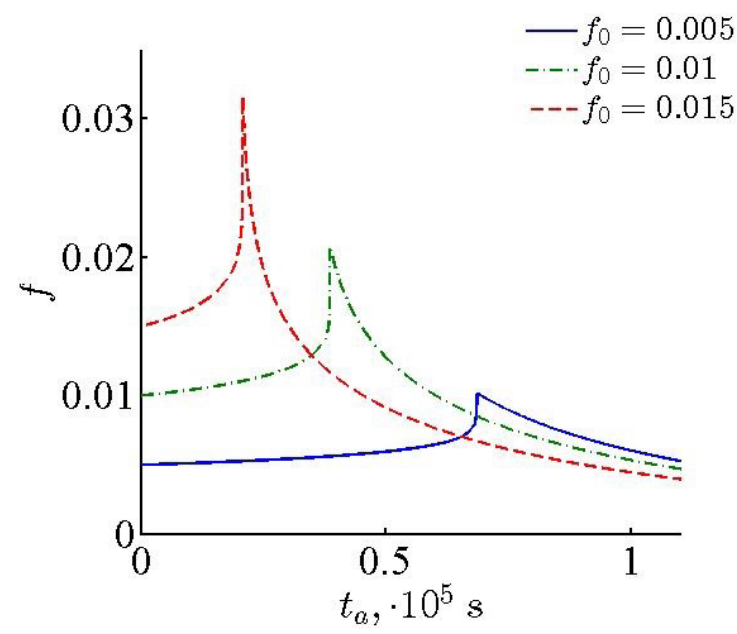

b

Fig. 1. Dependence of the value of the relative nonequilibrium free volume $f$ on the annealing time $t_{a}$ : for different initial values of the volume fraction of grain-boundary cavities $v_{0}$ and the initial value of the nonequilibrium free volume $f_{0}=10^{-2}(\mathrm{a})$; for different initial values of $f_{0}$ and the initial volume fraction of cavities $v_{0}=5 \cdot 10^{-3}(\mathrm{~b})$.

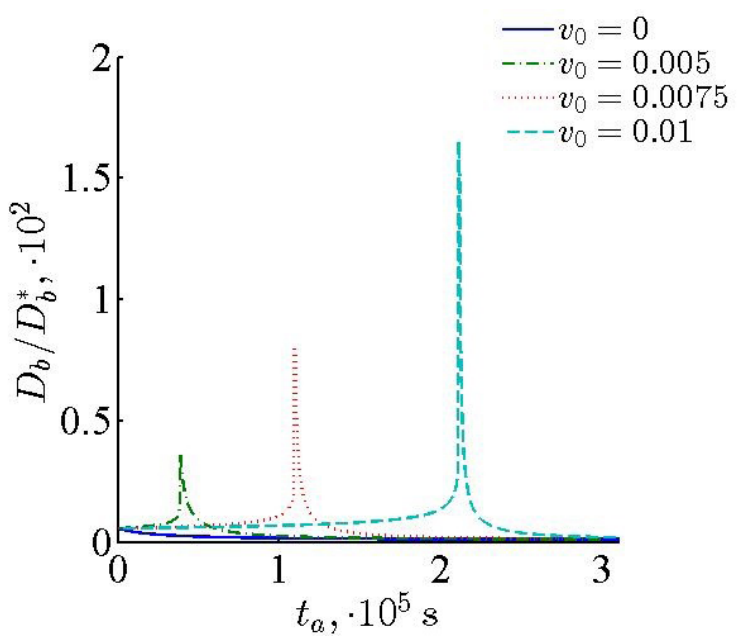

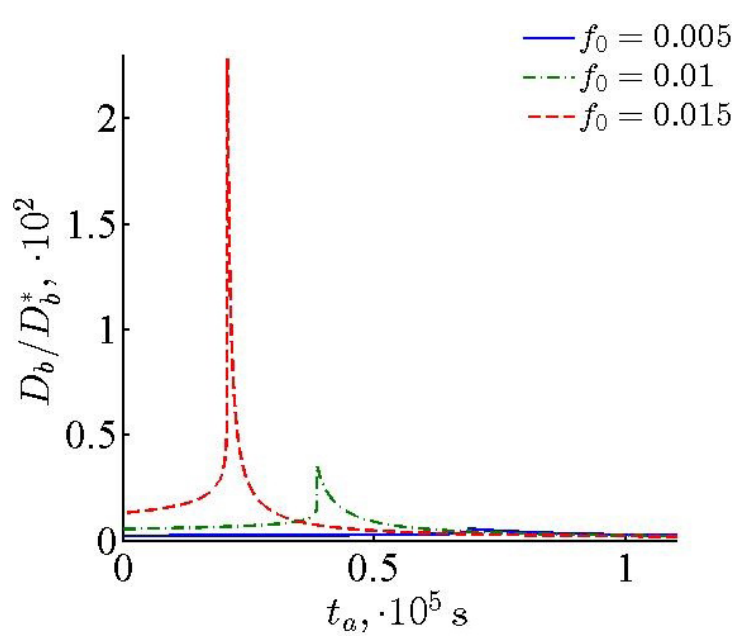

$\mathrm{b}$

Fig. 2. Dependence of the value of the grain-boundary diffusion coefficient $D_{b}$ on the annealing time $t_{a}$ : for different initial values of the volume fraction of grain-boundary cavities $v_{0}$ and the initial value of the nonequilibrium free volume $f_{0}=10^{-2}(\mathrm{a})$; for different initial values of $f_{0}$ and the initial volume fraction of cavities $v_{0}=5 \cdot 10^{-3}(\mathrm{~b})$.

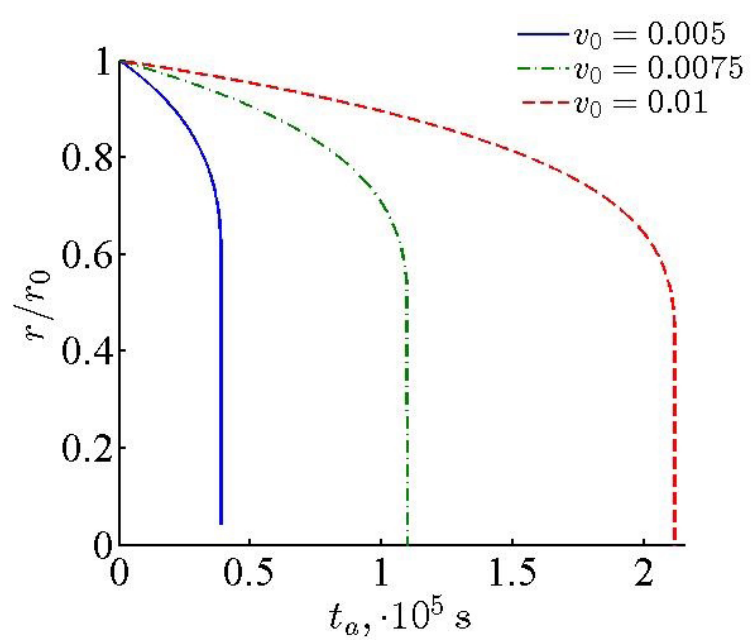

a

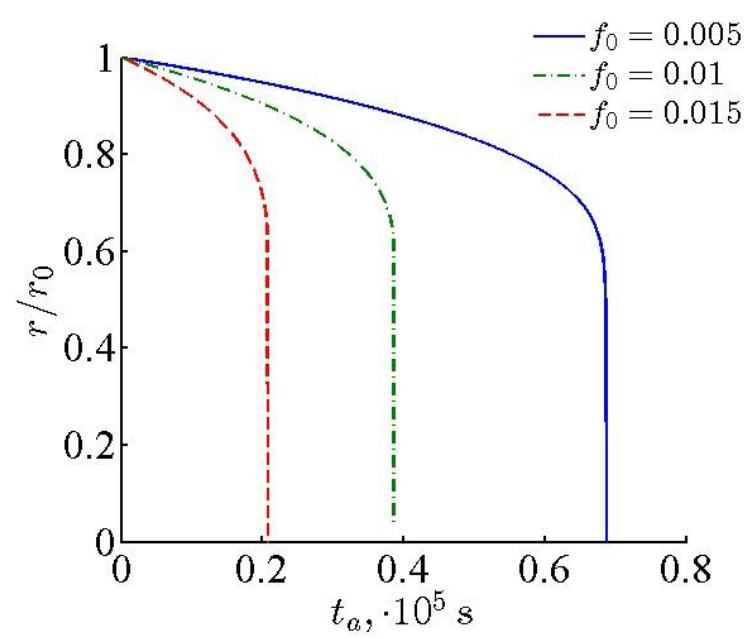

$\mathrm{b}$

Fig. 3. Dependence of the radius of grain-boundary cavities $r$ on the annealing time $t_{a}$ : for different initial values of the volume fraction of grain-boundary cavities $v_{0}$ and the initial value of the nonequilibrium free volume $f_{0}=10^{-2}(\mathrm{a})$; for different initial values of $f_{0}$ and the initial volume fraction of cavities $v_{0}=5 \cdot 10^{-3}(\mathrm{~b})$. 
of grain-boundary diffusion change only slightly. An increase in the initial value of the volume fraction of grain-boundary cavities $v_{0}$ at a given initial value of the nonequilibrium free volume slows down the cavity dissolution process (Fig. $3 \mathrm{a}$ ) and increases the duration of this stage (Fig. 1a, $2 \mathrm{a}$ ). An increase in the initial value of the nonequilibrium free volume of the GB $f_{0}$ for a given value of the initial volume fraction of cavities has the opposite effect on its duration (Fig. 1b, 2 b). In the second stage, a rapid increase in the values of $f$ and $D_{b}$ occurs, which is associated with a sharp increase in the rate of cavity dissolution with a decrease in the cavity size to a certain critical value (Fig. 3). At this stage, the coefficient of grain-boundary diffusion increases by 1-2 orders of magnitude. The annealing time, corresponding to the maximum values of the nonequilibrium free volume and the coefficient of grain boundary diffusion, characterizes the termination of the process of dissolution of grain boundary nanocavities. At the third stage, the process of relaxation of the nonequilibrium free volume of the GB and the decrease in the coefficient of grain-boundary diffusion due to the outflux of vacancies from the GB to the neighboring grain volume occurs.

The decrease in the duration of the first stage with increasing $f_{0}$ (Fig. 1b, 2b) is due to the fact that with increasing $f_{0}$, according to expression (6), the initial cavity radius $r_{0}$ decreases, the process of their dissolution occurs faster and the critical cavity size, at which a loss of their stability occurs, is achieved sooner (Fig. $3 \mathrm{~b}$ ).

Thus, the results of the work show that, contrary to popular belief that annealing is always accompanied by the transition of a GB to a more equilibrium state, in the case of low-temperature annealing of SMC materials containing the initial state of grain-boundary cavities, the reverse process can occur - an increase in the degree of nonequilibrium of GBs, caused by a change in their nonequilibrium free volume during cavity dissolution. This circumstance leads to the fact that with a sufficiently large initial volume fraction of grainboundary cavities, the free volume of GBs and the coefficient of grain-boundary diffusion can, under conditions of lowtemperature annealing, differ significantly for a long time from their values in the equilibrium GB.

\section{Conclusions}

1. A model is proposed that allows one to describe the effect of the nonequilibrium free volume of grain boundaries and the volume fraction of grain-boundary cavities on the evolution of the diffusion properties of nonequilibrium grain boundaries during low-temperature annealing of SMC materials.

2. It is shown that the process of dissolution of grainboundary cavities leads to an increase in the coefficient of grain-boundary diffusion and allows one to maintain a substantially nonequilibrium state of grain boundaries under conditions of prolonged annealing.

Acknowledgements. The work was performed as part of the government assignment for conducting fundamental scientific research for 2013-2020 by the IAP RAS, task No. 0035-2014-0401.

\section{Литература/References}

1. R.Z. Valiev, I. V. Aleksandrov. Nanostructured materials processed by the methods of severe plastic deformation. Moscow, Logos. (2000). 272 p. (in Russian). ) [Р. З. Валиев, И.В. Александров. Наноструктурные материалы, полученные интенсивной пластической деформацией. Москва, Логос. (2000). 272 с.]

2. Yu. R. Kolobov, R. Z. Valiev, G. P. Grabovetskaya et al. Grain boundary diffusion and properties of nanostructured materials. Novosibirsk, Nauka. (2001). 232 p. (in Russian). [Ю.Р. Колобов, Р.3. Валиев, Г.П. Грабовецкая и др. Зернограничная диффузия и свойства наноструктурных материалов. Новосибирск, Наука. (2001). 232 с.]

3. V.I. Betekhtin, Yu.R. Kolobov, V. Sklenicka, A. G. Kadomtsev, M. V. Narykova, J. Dvorak, E. V. Golosov, B. K. Kardashev, I. N. Kuz'menko. Tech. Phys. 60, 66 (2015). DOI: 10.1134/S1063784215010041

4. V.I. Betekhtin, V. Sklenička, A.G. Kadomtsev, Yu. R. Kolobov, M. V. Narykova. Phys. Solid State. 59, 960 (2017). DOI: 10.1134/S1063783417050043

5. Yu.R. Kolobov, G.P. Grabovetskaya, I. V. Ratochka, K. V. Ivanov. Russ. Phys. Journ. 41, 260 (1998). DOI: $10.1007 / B F 02766422$

6. Yu.R. Kolobov, G.P. Grabovetskaya, K.V. Ivanov, N.V. Girsova. Phys. Metals Metallogr. 90 No. 5, 105 (2001). (in Russian). [Ю. Р. Колобов, Г. П. Грабовецкая, К. В. Иванов, Н. В. Гирсова. ФММ. 90, № 5, 105 (2001).]

7. Yu.R. Kolobov, G.P. Grabovetskaya, K.V. Ivanov, M. B. Ivanov. Interface Sci. 10, 31 (2002). DOI: $10.1023 /$ A:1015128928158

8. Yu. R. Kolobov, G.P. Grabovetskaya, K. V. Ivanov. Ann. Chim. Sci. Mat. 27, 89 (2002).

9. G. P. Grabovetskaya. Phys. Mesomech. 8. No. 2, 49 (2005). (in Russian). [Г. П. Грабовецкая. ФМ. 8, № 2, 49 (2005).]

10. V.N. Perevezentsev, M.Yu. Scherban', T.A. Gracheva, T. A. Kuz'micheva. Tech. Phys. 60, 1167 (2015).

11. V.I. Betekhtin, A.G. Kadomtsev, V. Sklenicka, I. Saxl. Phys. Solid State, 49, 1874 (2007). DOI: 10.1134/S1063783407100101

12. V.I. Betekhtin, V. Sklenicka, I. Saxl, B. K. Kardashev, A. G. Kadomtsev, M. V. Narykova. Phys. Solid State. 52, 1629 (2010). DOI: 10.1134/S1063783410080111

13. V.I. Betekhtin, E.D. Tabachnikova, A.G. Kadomtsev, M. V. Narykova, R. Lapovok. Tech. Phys. Lett. 37, 767 (2011). DOI: 10.1134/S1063785011080189

14. V.V. Mishakin, V.N. Perevezentsev, M. Yu. Scherban', V.A. Klyushnikov, T.A. Gracheva, T.A. Kuz'micheva. Russ. J. Nondestr. Testing. 6, 57 (2015). (in Russian). [В. В. Мишакин, В.Н. Перевезенцев, М. Ю. Щербань, В.А. Клюшников, Т.А. Грачева, Т.А. Кузьмичева. Дефектоскопия. 6, 57 (2015).]

15. X. Sauvage, R. Pippan. Mater. Sci. Eng. A, 410-411, 345 (2005). DOI: 10.1016/j.msea.2005.08.122

16. J. Ribbe, D. Baither, G. Schmitz, S. V. Divinski. Scripta Mater. 61, 129 (2009). DOI: 10.1016/j.scriptamat.2009.03.029

17. V.I. Betekhtin, E.D. Tabachnikova, A.G. Kadomtsev, M. V. Narykova, R. Lapovok. Tech. Phys. Lett. 37, 767 (2011). DOI: 10.1134/S1063785011 
18. J. Čížek, M. Janeček, O. Srba, R. Kužel, Z. Barnovská, I. Procházka, S. V. Dobatkin. Acta Mater. 59, 2322 (2011). DOI: 10.1016/j.actamat.2010.12.028

19. J. Čížek, I. Procházka, M. Cieslar, I. Stuliková, F. Chmelik, R. K. Islamgaliev. Phys. Stat. Solidi (a). 191, 391 (2002). DOI: $\quad 10.1002 / 1521-396 X(200206) 191: 2<391:: A I D-$ PSSA391>3.0.CO;2-H

20. S. Van Petegem, F. Dalla Torre, D. Segers, H. Van Swygenhoven. Scripta Mater. 48, 17 (2003). DOI: 10.1016/S1359-6462(02)00322-6

21. S. V. Divinski, G. Reglitz, H. Rosner, Y. Estrin, G. Wilde. Acta Mater. 59, 1974 (2011). DOI: $10.1016 /$ j.actamat.2010.11.063

22. R. Lapovok, D. Tomus, J. Mang, Y. Estrin, T.C. Lowe. Acta Mater. 57, 2909 (2009). DOI: 10.1016/j.actamat.2009.02.042

23. V.I. Betekhtin, Yu.R. Kolobov, M.V. Narykova, B. K. Kardashev, E. V. Golosov, A. G. Kadomtsev. Tech. Phys. 56, 1599 (2011). DOI: 10.1134/S1063784211110053

24. I. A. Ovid'ko, A. G. Sheinerman, N. V. Skiba. Acta Mater. 59, 678 (2011). DOI: 10.1016/j.actamat.2010.10.005

25. L. Klinger, E. Rabkin, L.S. Shvindlerman, G. Gottstein. J. Mater. Sci. 43, 5068 (2008). DOI: $10.1007 /$ s10853-008-2678-y

26. J. Ribbe, G. Schmitz, D. Gunderov, Y. Estrin, Y. Amouyal, G. Wilde, S. V. Divinski. Acta Mater. 61, 5477 (2013). DOI: 10.1016/j.actamat.2013.05.036

27. V.N.Perevezentsev, A.S.Pupynin, A. E. Ogorodnikov. Tech. Phys. 63, 1492 (2018). DOI: 10.1134/S1063784218100171

28. V.V. Rybin, A.A. Zisman, N.Yu. Zolotorevsky.
Acta metall. mater. 41, 2211 (1993). DOI: 10.1016/0956-7151(93)90390-E

29. V. N. Perevezentsev, V. V. Rybin. Structure and properties of grain boundaries. Nizhni Novgorod, Lobachevsky State University of Nizhni Novgorod. (2012). 307 p. (in Russian). [В.Н. Перевезенцев, В.В. Рыбин. Структура и свойства ГЗ. Нижний Новгород, Изд-во Нижегородского госуниверситета им. Н. И. Лобачевского (2012). 307 с.]

30. S. V. Kirikov, V.N. Perevezentsev, Yu. V. Svirina. Deformation and fracture of materials. 3, 20 (2018). (in Russian). [С.В. Кириков, В.Н. Перевезенцев, Ю.В. Свирина. Деформация и разрушение материалов. 3, 20 (2018).]

31. V. N. Perevezentsev. Phys. Metals Metallogr. 93, No. 3, 15 (2002). (in Russian). [В.Н. Перевезенцев. ФММ. 93, № 3, 15 (2002).]

32. V.N. Perevezentsev, A.S. Pupynin, Yu. V. Svirina. Phys. Metals Metallogr. 100, No. 1, 17 (2005). (in Russian). [В.Н. Перевезенцев, А.С. Пупынин, Ю.В. Свирина. ФММ. 100, №1, 17 (2005).]

33. V.N. Perevezentsev, A.S. Pupynin, Yu. V. Svirina. Mater. Sci.Eng. A. $410-411,273$ (2005). DOI: $10.1016 /$ j.msea.2005.08.002

34. V.N. Perevezentsev, A.S. Pupynin. Tech. Phys. Lett. 37, 287 (2011). DOI: 10.1134/S106378501103028X

35. H. J. Frost, M. F. Ashby. Deformation-Mechanism Maps. Chelyabinsk, Metallurgy. (1989). 328 p. (in Russian). [Г. Дж.Фрост, М. Ф.Эшби Карты механизмов деформации. Пер. с англ. под ред. Берштейна Л. М. Челябинск: Металлургия, Челябинское отделение, 1989, 328 с.] 